\title{
Amostral Optimization of Mechanical Resistance to the Penetration of a Yellow Oxisol Under Pasture
}

\author{
Fabiane Pereira Machado Dias ${ }^{1}$, Ésio de Castro Paes ${ }^{2}$, Flávia de Jesus Nunes ${ }^{3}$, Ana Carolina Rabelo Nonato ${ }^{3}$, \\ Neilon Duarte da Silva ${ }^{3}$, Fabiano de Oliveira de Paula Oliveira ${ }^{3}$, Ludmila Gomes Fereira $^{3}$ \\ \& Júlio César Azevedo Nóbrega ${ }^{3}$ \\ ${ }^{1}$ Goias Federal University, Brazil \\ ${ }^{2}$ Federal University of Viçosa, Brazil \\ ${ }^{3}$ Federal University of the Reconcavo of Bahia, Brazil \\ Correspondence: Júlio César Azevedo Nóbrega, Federal University of Recôncavo da Bahia, Rui Barbosa Avenue, \\ 710, Downtown, CEP 44380-000, Cruz das Almas, Bahia, Brazil. E-mail: jcanobrega@gmail.com
}

Received: May 14, 2018

doi:10.5539/jas.v10n9p275
Accepted: June 28, 2018 Online Published: August 15, 2018

URL: https://doi.org/10.5539/jas.v10n9p275

\begin{abstract}
The degradation of pastures can be characterized by several factors, mainly due to the management adopted, so in view of the country's territorial extension and the peculiarity of each region and soil type, it is essential to develop research to improve the monitoring of the system. The objective of this study was to evaluate the effect of different sample densities to establish a mesh that gives precision in maps of spatial variability of soil mechanical resistance to root penetration to pasture areas in the coastal tableland region of Northeast Brazil. In a pasture area, three sampling meshes were demarcated for georeferenced evaluation of soil mechanical resistance to root penetration: mesh 1 established in the dimensions of $50 \times 50 \mathrm{~m}$, mesh 2 of $100 \times 100 \mathrm{~m}$ and mesh 3 of $150 \times 150 \mathrm{~m}$, totaling an area of 9 ha. The soil resistance to penetration was measured using an automated apparatus, coupled to a tractor. The variation found in the values of penetration resistance in subsurface can be related to the management adopted in the area, as well as the trampling of the animals. Data on soil penetration resistance in pasture showed that the most compacted zone was always below $30 \mathrm{~cm}$ depth by using different sample densities. The results allow us to conclude that the higher the density of the sampling mesh, the greater the accuracy of the data and that, independently of the sample mesh, it was possible to identify the layer of higher soil mechanical resistance to root penetration.
\end{abstract}

Keywords: compaction, sample density, geostatistics, coastal tableland

\section{Introduction}

Brazil has a total area of natural pastures planted around 172 million hectares (IBGE, 2007), approximately 20\% of the national territory, much of which has already reached some level of degradation, whether of a physical, chemical or biological nature. In these areas under pasture in Brazil the predominant soils are Oxisols and Ultisols, which commonly present serious fertility problems (Bomfim et al., 2003).

Livestock farming is one of the few agricultural activities that, even with the use of few technologies and inputs, can be exploited, unlike what happens with grain production, for example, requiring a large subsidy and adoption of technologies to be successful in production (Dias-Filho, 2014). In this sense, the areas under pasture due to the ease of management, generate a consequent reduction of investment and use of technology, which converges for rapid degradation of these areas in the country, making the activity basically harmful to the environment.

Recovery of degraded pastures as well as fertility management and monitoring of soil attributes under pasture may be important tools for improving and maintaining pasture quality, which would reduce the need to open new areas in different regions of Brazil (Andrade et al., 2016).

The soil mechanical resistance to penetration is a device used to evaluate changes in soil structure, at the same time it also serves to monitor soil compaction levels, or even point to inadequate management (Gomes et al., 2015). When associated with the geostatistics tool, it is possible to identify specific areas where any kind of impediment to root development is occurring, facilitating localized management. 
Thus, several studies have sought to identify the most adequate sampling density capable of assuring a reliable average value that allows systematic sampling for the management of soil attributes (Grego \& Vieira, 2005; Kestring et al., 2015; Guedes et al., 2016; Dias et al., 2017), since the optimization of the appropriate sampling system aims at reducing production costs through localized management.

The coastal tableland, where the study was developed, cover the entire coast of Northeast Brazil, being characterized by flat soils with low natural fertility and high depth. Several studies have pointed out that the main problems of the tableland soils are associated with the water deficit and the requirement of the cohesive layer, which reduces the effective depth, especially of the Oxisols. Thus, the objective of this study was to evaluate the effect of different sample densities to establish a mesh that gives precision in maps of spatial variability of soil mechanical resistance to root penetration to the areas under pasture in the coastal tableland region of Northeast Brazil.

\section{Material and Methods}

The study was carried out at the Federal University of Recôncavo of Bahia-UFRB, Cruz das Almas University Campus, in the Coastal tablelands region of Bahia, Northeast Brazil. The geographical coordinates are $12^{\circ} 39^{\prime} 33.9^{\prime \prime} \mathrm{S} ; 39^{\circ} 05^{\prime} 16.6^{\prime \prime} \mathrm{W}$, with an altitude of 226 meters. According to the classification of Köppen the climate of the region is of the hot and humid tropical type, with great part of its soil constituted by yellow oxisols and yellow ultisol. The mean annual rainfall and temperature are around $1200 \mathrm{~mm}$ and $24.5^{\circ} \mathrm{C}$, respectively.

In a pasture area under a conventional management system in a Distrocoesus Yellow oxisol, three sample meshes were demarcated for georeferenced evaluation of soil mechanical resistance to root penetration: mesh 1 established in the dimensions of $50 \times 50 \mathrm{~m}$ (49 collection points), mesh 2 in the dimensions of $100 \times 100 \mathrm{~m}(16$ collection points) and mesh 3 in the dimensions of $150 \times 150 \mathrm{~m}$ (9 collection points), totaling an area of 9 ha (Figure 1). The penetration resistance values were obtained at each of the sampling points of the three meshes. The sampling points of each mesh were georeferenced in UTM coordinates, using a GPS device with an average accuracy of $5 \mathrm{~m}$.

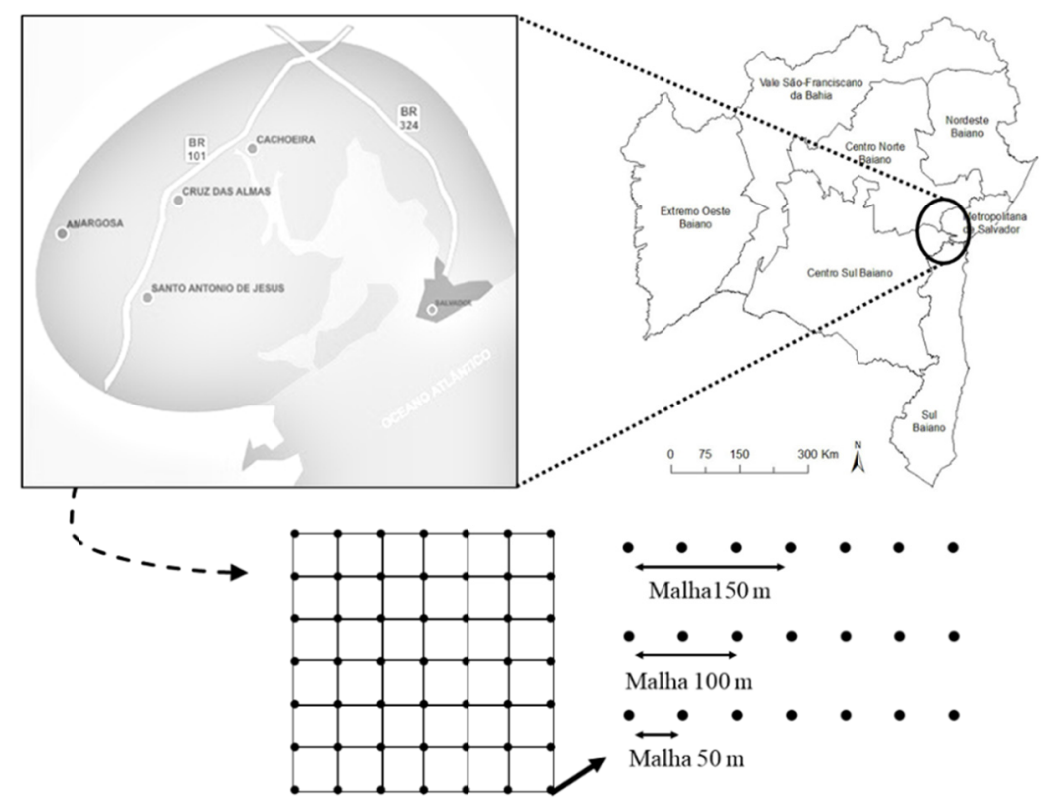

Figure 1. Location and sampling scheme of the soil in the different sampling meshes in a Yellow Oxisol of the Coastal tablelands region of Bahia

The soil resistance to penetration was measured using an automated FALKER model, SOLO STAR model, coupled to a tractor and equipped with a cone-shaped tip and a 30-degree vertex angle, with automatic measurement and resolution system depth set to $1 \mathrm{~cm}$; with a maximum depth of $60 \mathrm{~cm}$, complying with the standard established by ASABE S313.3 (Asabe, 2006). 
Parallel to the penetration resistance evaluations, soil samples were also collected in the $0.0-0.10,0.10-0.20$ and 0.20-0.40 m layers to determine the soil moisture after drying in an oven for $24 \mathrm{~h}$ at $105^{\circ} \mathrm{C}$.

The spatial maps were calculated using the Inverse Distance Weighting (IDW), using the geostatistical analysis, which is important for analyzing the spatial variability of the data, according to the patterned surface. Digital models were generated for each of the meshes to estimate the soil mechanical resistance to root penetration.

Data was analyzed through descriptive statistics, obtaining mean, variance, standard deviation, coefficient of variation, asymmetry and kurtosis, in order to have an overview of how the data behaved. The normality hypothesis of the data was tested by the Kolmogorov-Smirnov test.

\section{Results and Discussion}

Table 1 presents the values of the descriptive statistical analysis of the soil penetration resistance for three different densities of the sample mesh studied. It was observed that not all evaluated depths show normal distribution of the data, in terms of the values of asymmetry and kurtosis, when they were near or equal to zero it indicates whether the variable has a normal distribution or not, this way as the asymmetry and kurtosis values were not high, geostatistical analysis was performed even though normality is not a condition to use geostatistics.

The coefficient of variation (CV) data presented values considered low in all depths and sample meshes studied, not exceeding $14 \%$, suggesting that there was little data variability in relation to the average, demonstrating a homogeneous distribution.

The variation found in the values of resistance to penetration in subsurface can be related to the management of the animals adopted in the area (Imhoff et al., 2000). As the area is managed under pasture, the greatest changes in the physical structure of the soil occur in this layer, that is, they can be due to the mechanical action produced by the traffic of agricultural machinery or even by the action of trampling the animals. Thus, it is assumed that the greater variability of resistance to soil penetration in subsurface is accentuated by the interaction of the mentioned factors that occur in the soil, so that, as soil depth increases, the amplitude and the heterogeneity of the penetration resistance values observed, as evidenced by the CV (Table 1). 
Table 1. Descriptive statistics for resistance to penetration in samples collected in the three sample meshes at depths of $0.0-0.10 ; 0.10-0.20 ; 0.20-0.30 ; 0.30-0.40 ; 0.40-0.50$ and $0.50-0.60 \mathrm{~m}$ of a Yellow Oxisol under pasture in the region of coastal tablelands of Bahia

\begin{tabular}{|c|c|c|c|c|c|c|}
\hline Statistics & Malha 1 & Malha 2 & Malha 3 & Malha 1 & Malha 2 & Malha 3 \\
\hline & \multicolumn{3}{|c|}{$0.0-0.10 \mathrm{~m}$} & \multicolumn{3}{|c|}{$0.10-0.20 \mathrm{~m}$} \\
\hline Mínimo & 0.08 & 0.39 & 0.51 & 1.54 & 1.69 & 1.69 \\
\hline Máximo & 2.10 & 2.11 & 2.11 & 7.03 & 7.03 & 7.03 \\
\hline Média & 0.94 & 0.96 & 0.99 & 2.38 & 2.42 & 2.51 \\
\hline Mediana & 0.89 & 0.87 & 0.91 & 2.12 & 2.15 & 2.18 \\
\hline Desvio padrão & 0.39 & 0.38 & 0.41 & 1.08 & 1.03 & 1.17 \\
\hline Assimetria & 0.37 & 1.31 & 1.26 & 3.38 & 3.64 & 3.21 \\
\hline Curtose & 1.01 & 2.19 & 1.50 & 12.41 & 15.42 & 11.76 \\
\hline${ }^{1} \mathrm{CV}(\%)$ & 0.15 & 0.14 & 0.17 & 1.17 & 1.07 & 1.37 \\
\hline \multirow[t]{2}{*}{${ }^{2} \mathrm{~d}$} & 0.08 & 0.19 & 0.17 & 0.29 & 0.28 & 0.28 \\
\hline & \multicolumn{3}{|c|}{$0.20-0.30 \mathrm{~m}$} & \multicolumn{3}{|c|}{$0.30-0.40 \mathrm{~m}$} \\
\hline Mínimo & 1.54 & 1.54 & 1.54 & 1.05 & 1.34 & 1.05 \\
\hline Máximo & 10.99 & 10.99 & 10.99 & 15.64 & 14.97 & 14.97 \\
\hline Média & 3.31 & 3.33 & 3.79 & 4.83 & 4.78 & 4.73 \\
\hline Mediana & 2.31 & 2.14 & 2.31 & 3.04 & 3.08 & 3.34 \\
\hline Desvio padrão & 2.29 & 2.54 & 3.03 & 3.59 & 3.55 & 3.62 \\
\hline Assimetria & 1.91 & 2.09 & 1.44 & 1.36 & 1.43 & 1.50 \\
\hline Curtose & 2.99 & 3.54 & 0.63 & 1.26 & 1.24 & 1.99 \\
\hline${ }^{1} \mathrm{CV}(\%)$ & 5.23 & 6.45 & 9.20 & 12.89 & 12.60 & 13.08 \\
\hline \multirow[t]{2}{*}{${ }^{2} \mathrm{~d}$} & 0.27 & 0.29 & 0.31 & 0.22 & 0.27 & 0.24 \\
\hline & \multicolumn{3}{|c|}{$0.40-0.50 \mathrm{~m}$} & \multicolumn{3}{|c|}{$0.50-0.60 \mathrm{~m}$} \\
\hline Mínimo & 1.63 & 1.96 & 1.63 & 2.11 & 2.11 & 2.94 \\
\hline Máximo & 13.08 & 13.08 & 13.08 & 14.21 & 13.84 & 14.21 \\
\hline Média & 5.93 & 5.68 & 5.51 & 7.96 & 7.80 & 7.38 \\
\hline Mediana & 4.88 & 4.77 & 4.66 & 7.21 & 7.04 & 7.06 \\
\hline Desvio padrão & 3.56 & 3.38 & 3.50 & 3.53 & 3.60 & 3.74 \\
\hline Assimetria & 0.65 & 1.01 & 0.86 & 0.11 & 0.20 & 0.47 \\
\hline Curtose & -0.99 & -0.11 & -0.28 & -1.29 & -1.28 & -1.12 \\
\hline${ }^{1} \mathrm{CV}(\%)$ & 12.66 & 11.39 & 12.24 & 12.48 & 12.96 & 13.96 \\
\hline${ }^{2} \mathrm{~d}$ & 0.15 & 0.18 & 0.16 & 0.10 & 0.14 & 0.16 \\
\hline
\end{tabular}

Note. ${ }^{1} \mathrm{CV}=$ coefficient of variation; ${ }^{2} \mathrm{~d}=$ normality test by the Kolmogorov-Smirnov test.

Taking into account that the brachiaria roots concentrate to a greater extent in the depth of $0.20-0.30 \mathrm{~m}$, it can be inferred that according to the critical limits adopted (Figure 2) in the literature, the data of the present study present few limitations to pasture development. Soares et al. (2016) considered values of $2 \mathrm{MPa}$ as a significant compaction level, which may cause restriction to root development. In a study with pastures in Ultisol in the Amazon region, these authors attributed the high values of resistance to penetration in pasture areas, to inadequate animal design in the area, which causes changes in the physical structure of the soil, in general, contributing to the increased soil compaction and soil resistance to root penetration. 


\section{Compactação}

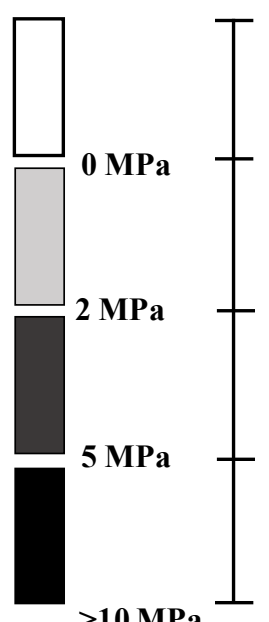

\section{Limitação às raízes}

Baixa $\longrightarrow \quad \begin{aligned} & \text { Nenhuma ou pouca } \\ & \text { limitação }\end{aligned}$ limitação

Moderada $\longrightarrow$ Algumas limitações

Alta

$\longrightarrow$ Sérias limitações

Muito alta

$\longrightarrow \quad \begin{aligned} & \text { Raízes praticamente não } \\ & \text { crescem }\end{aligned}$

Figure 2. Classes of soil compaction and degrees of root growth restriction adopted in the present study to classify mechanical resistance to soil penetration under pasture

The values of resistance to soil penetration in pasture showed through the use of different sample densities that the compacted zone was always below $30 \mathrm{~cm}$ depth. The high PR values found in depth may also be related to the low average humidity observed in the whole profile at the moment of data collection, around $9 \%$, in all the points sampled. It is worth mentioning that the values of resistance to penetration with a high amplitude of variation can be a reflection of small oscillations in the volume of water in the soil (Mion et al., 2012), because as lower the water content in the soil, the greater the soil resistance to root penetration tends to be.

Observing the spatial maps (Figure 3), it was possible to verify that the lower the density of the sampling mesh, the lower the accuracy of the data, especially in depth. Sampling meshes $2(100 \times 100)$ and $3(150 \times 150)$ were able to detect compacted zones with good accuracy up to $0.30 \mathrm{~m}$ depth. Although the amplitude of variation was practically the same in the different sample meshes for all the depths, the meshes 2 and 3 presented smaller numbers of classes of interpretation. 

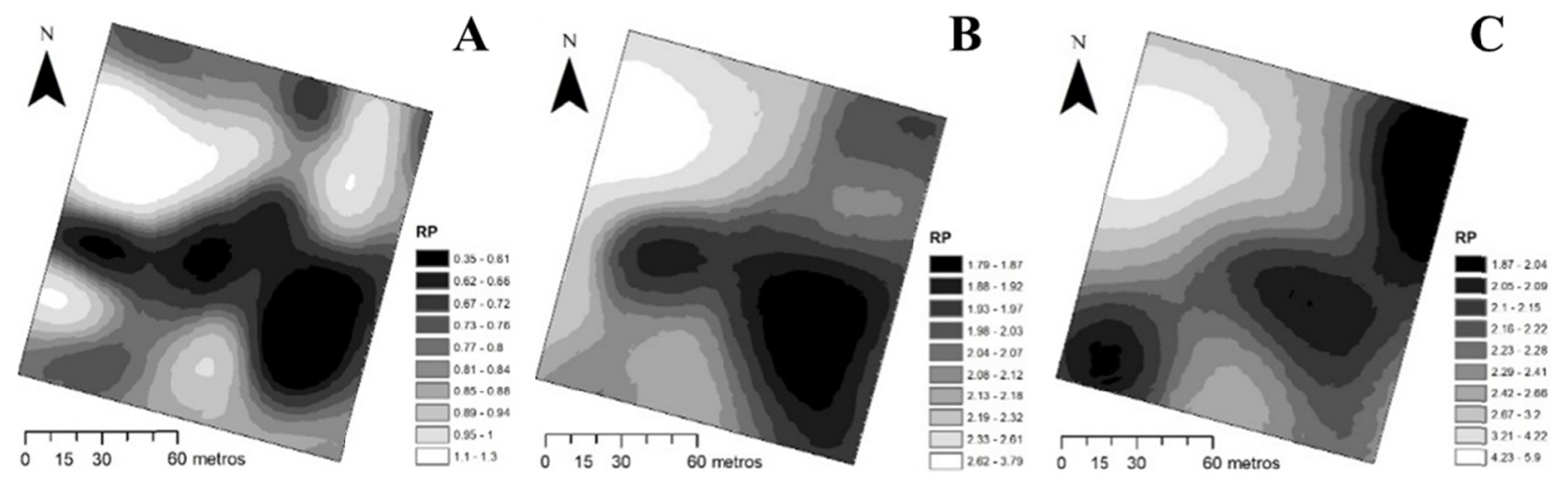

\section{D}
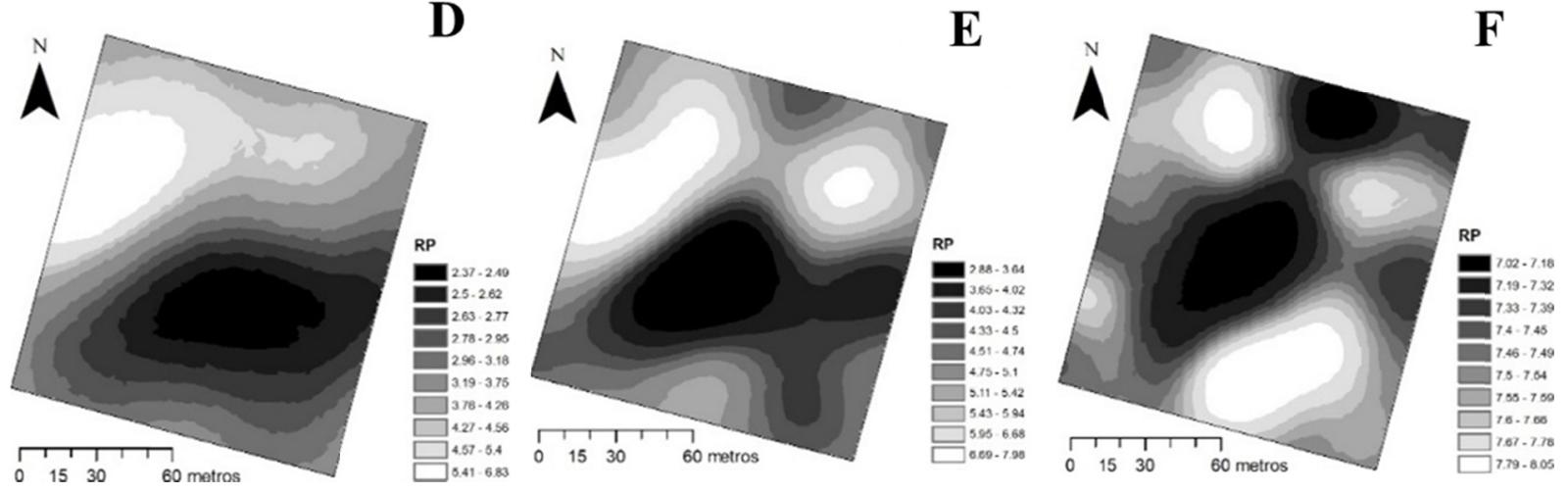

Figure 3. Maps of the spatial distribution of resistance values to soil penetration of mesh 1 with points distanced at $50 \times 50 \mathrm{~m}$ in a Yellow Oxisol under pasture. A, B, C, D, E and F correspond to the depths of 0.0-0.10; $0.10-0.20 ; 0.20-0.30 ; 0.30-0.40 ; 0.40-0.50$ and $0.50-0.60$, respectively

The mesh 1 of higher sample density $(50 \times 50 \mathrm{~m})$, although showing a greater accuracy of the data, the meshes 2 and 3 (Figures 4 and 5) allowed to identify that there is a vertical spatial variability with critical values of resistance to penetration, independent of the mesh size, it was possible to identify the layer of higher soil mechanical resistance to root penetration.

The data of the present study corroborate with Cherubim et al. (2011), who concluded in a study with Red Oxisol in the South of Brazil, that the mesh of lower sample density $(50 \times 50 \mathrm{~m})$ was the most adequate for identification of critical zones of resistance to penetration.

The increase in penetration resistance values as the depth of the profile is increased were also observed by Oliveira Filho et al. (2016) in the Northeast region of Brazil, obtaining maximum values around $13 \mathrm{MPa}$, that is, similar to that found in the present study. 

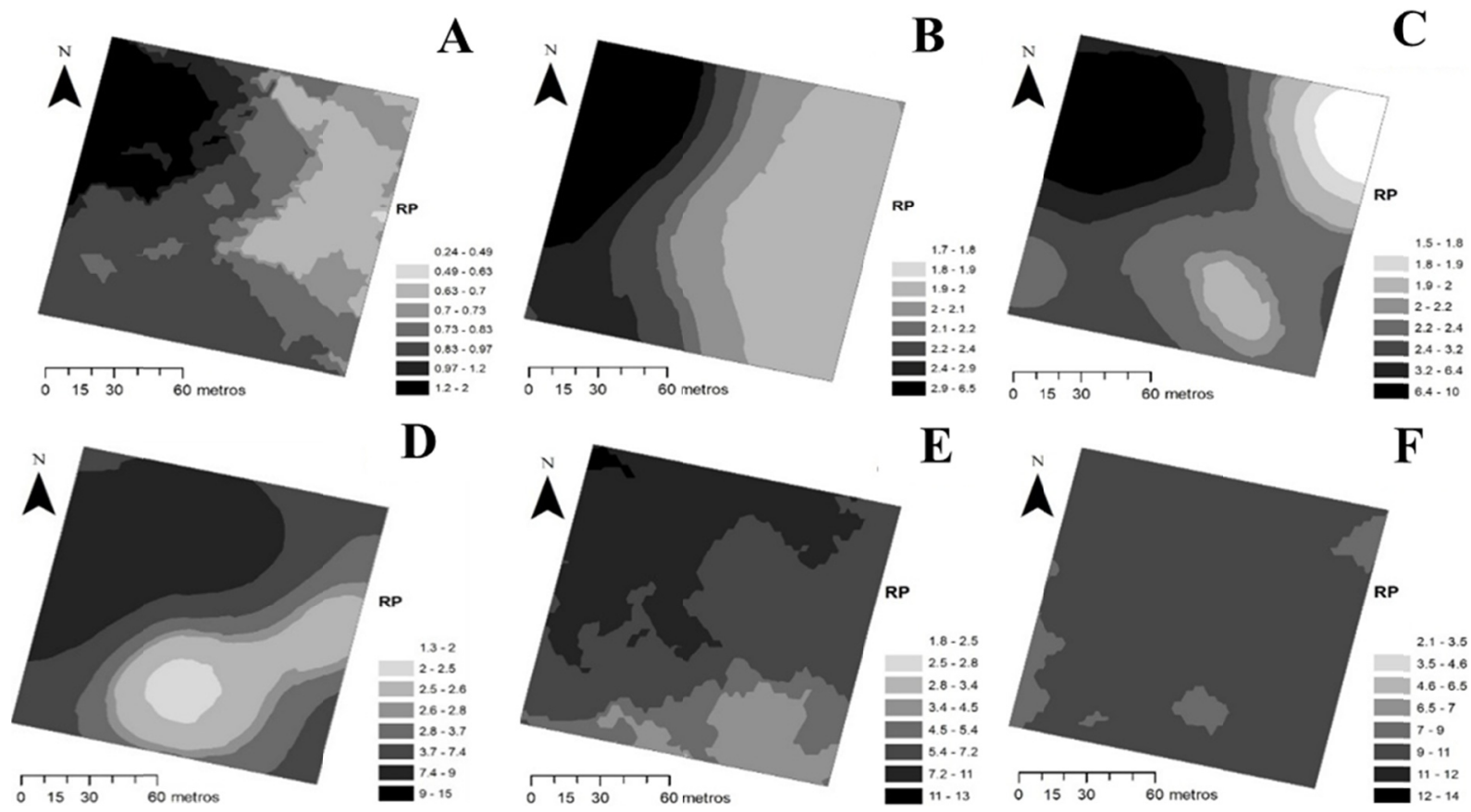

Figure 4. Maps of the spatial distribution of resistance values to the soil penetration of the mesh 2 with points distanced in $100 \times 100 \mathrm{~m}$ in a Yellow Oxisol under pasture. A, B, C, D, E and F correspond to the depths of $0.0-0.10 ; 0.10-0.20 ; 0.20-0.30 ; 0.30-0.40 ; 0.40-0.50$ and $0.50-0.60$, respectively

The results in the present study show that, although soil penetration resistance is considered a major cause of soil physical degradation, the use of penetration resistance as an indicator of compaction zones both superficially and along the profile is directly related with the sample density.
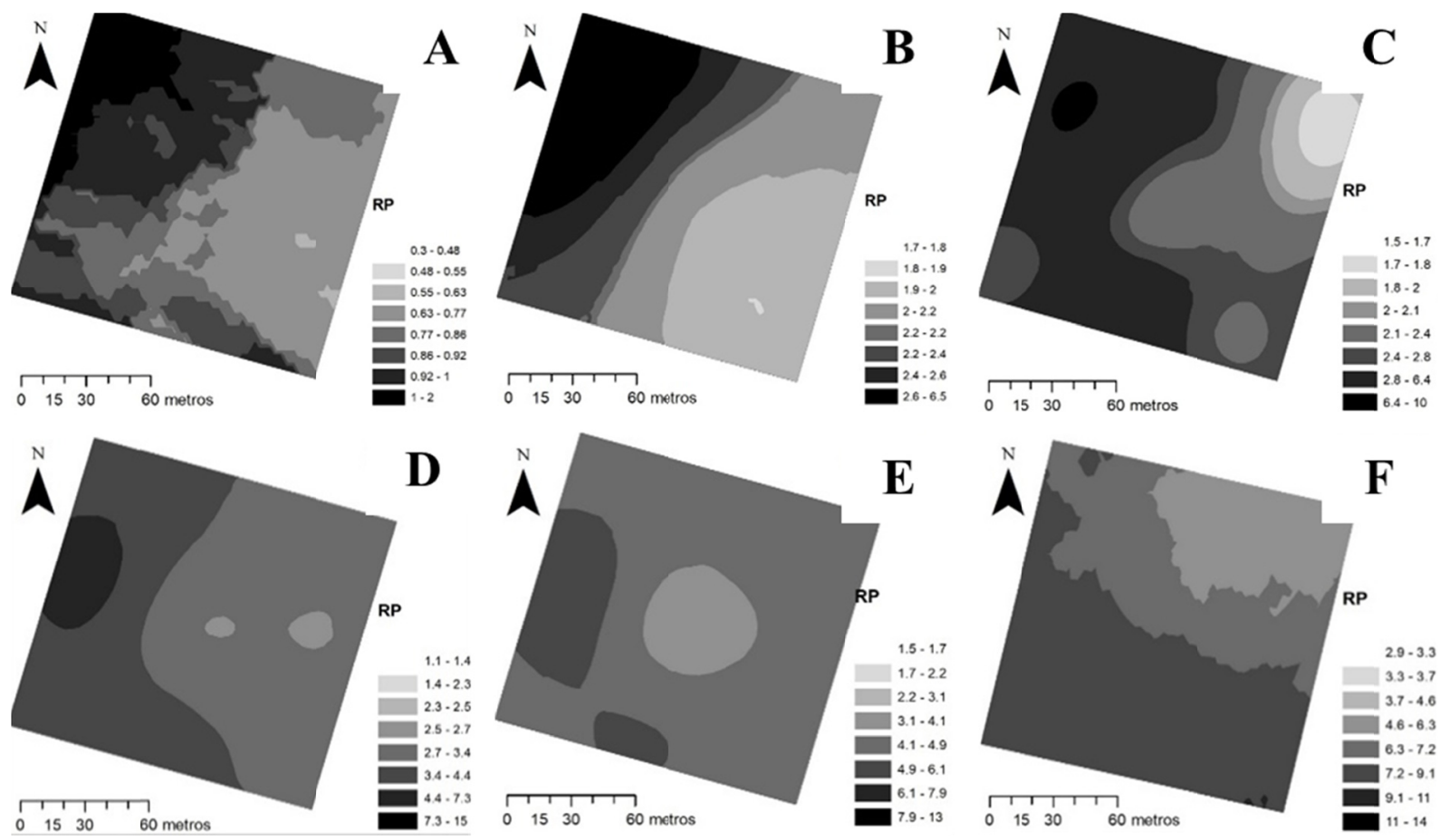

Figure 5. Maps of the spatial distribution of resistance values to soil penetration of mesh 3 with points distanced at $150 \times 150 \mathrm{~m}$ in a Yellow Oxisol under pasture. A, B, C, D, E and F correspond to the depths of 0.0-0.10; $0.10-0.20 ; 0.20-0.30 ; 0.30-0.40 ; 0.40-0.50$ and $0.50-0.60$, respectively 


\section{Conclusions}

(1) The mesh with lower sample density (50X50 m) was able to detect different scales of spatial variability, as well as to identify points with critical values of soil mechanical resistance to penetration with reliability up to $0.30 \mathrm{~m}$.

(2) Regardless of the sample mesh adopted, it was possible to identify the layer of higher soil mechanical resistance to root penetration.

(3) The use of geostatistics has proved to be an important tool in the understanding of soil resistance to penetration and can contribute to the decision making aimed at optimizing and improving pasture management.

\section{References}

Andrade, R. G., Bolfe, É. L., Victoria, D. C., \& Nogueira, S. F. (2016). Recuperação de pastagens no cerrado. AgroANALYSIS, 36(2), 30-32.

ASABE. American Society of Agricultural and Biological Engineers. (2006). Soil cone penetrometer. ASABE Standard S313.2 (pp. 903-904). St. Joseph, USA.

Bomfim, E. R. P., Pinto, J. C., Salvador, N., Morais, A. D., Andrade, I. D., \& Almeida, O. D. (2003). Efeito do tratamento físico associado à adubação em pastagem degradada de braquiária, nos teores de proteína bruta, fibra em detergente neutro e fibra em detergente ácido. Ciência e Agrotecnologia, 27(4), 912-920. https://doi.org/10.1590/S1413-70542003000400025

Cherubin, M. R., Santi, A. L., Basso, C. J., Eitelwein, M. T., \& Vian, A. L. (2011). Variabilidade da resistência a penetração do solo em função da dimensão da malha amostral. Revista Plantio Direto, 4-9.

Dias-Filho, M. B. (2014). Diagnóstico das pastagens no Brasil. Embrapa Amazônia Oriental (Documentos 402).

Dias, F. P. M., Castro, J. R., Nunes, F. J., Nonato, A. C. R., Botelho Júnior, F. B., Fé, J. A. R., \& Nóbrega, J. C. A. (2017). Eficiência de Malhas Amostrais na Caracterização da Variabilidade Espacial de Atributos Físicos do Solo. Anuário do Instituto de Geociências, 40(2), 31-36. https://doi.org/10.11137/2017_2_31_36

Guedes, L. P., Junior, R., Paulo, J., Uribe-Opazo, M. A., \& Bastiani, F. D. (2016). Soybean yield maps using regular and optimized sample with different configurations by simulated annealing. Engenharia Agrícola, 36(1), 114-125. https://doi.org/10.1590/1809-4430-Eng.Agric.v36n1p114-125/2016

Gomes, R. L. R., Silva, M. C., Costa, F. R., Lima Junior, A. F., Oliveira, I. P., \& Silva, D. B. (2015). Propriedades físicas e teor de matéria orgânica do solo sob diferentes coberturas vegetais. Revista Eletrônica Faculdade Montes Belos, 9(1), 72-85.

Grego, C. R., \& Vieira, S. R. (2005). Variabilidade espacial de propriedades físicas do solo em uma parcela experimental. Revista Brasileira de Ciência do Solo, 29(2), 169-177. https://doi.org/10.1590/S0100-0683 2005000200002

IBGE. (2007). Até 1996, dados extraídos de: Estatística do Século XX. Censo agropecuário 1920/2006. Rio de Janeiro: IBGE. Retrieved February 20, 2018, from http://seriesestatisticas.ibge.gov.br

Imhoff, S., Silva, A. P., \& Tormena, C. A. (2000). Aplicações da curva de resistência no controle da qualidade física de um solo sob pastagem. Pesquisa Agropecuária Brasileira, 35(7), 1493-1500. https://doi.org/ 10.1590/S0100-204X2000000700025

Kestring, F. B., Guedes, L. P., Bastiani, F., \& Uribe-Opazo, M. A. (2016). Comparação de mapas temáticos de diferentes grades amostrais para a produtividade da soja. Engenharia Agrícola, 35(4), 733-743. https://doi.org/10.1590/1809-4430-Eng.Agric.v35n4p733-743/2015

Mion, R. L., Nascimento, E. M. S., Sales, F. A. L., Silva, S. F., Duarte, J. M. L., \& Sousa, B. M. (2012). Variabilidade espacial da porosidade total, umidade e resistência do solo à penetração de um Argissolo Amarelo. Semina: Ciências Agrárias, 33(6), 2057-2066. https://doi.org/10.5433/1679-0359.2012v33 n6p2057

Oliveira Filho, F. X., Miranda, N. O., Medeirosr, J. F., Silva, P. C. M., Mesquita, F. O., \& Costa, T. K. G. (2016). Compactação de solo cultivado com cana-de-açúcar em Baía Formosa, Rio Grande do Norte. Revista Ceres, 63(5). https://doi.org/10.1590/0034-737x201663050017 
Soares, M. D. R., Campos, M. C. C., Souza, Z. M., Brito, W. B. M., Franciscon, U., \& Castione, G. A. (2016). Variabilidade espacial dos atributos físicos do solo em área de Terra Preta Arqueológica sob pastagem em Manicoré, A M. Revista de Ciências Agrárias/Amazonian Journal of Agricultural and Environmental Sciences, 58(4), 434-441. https://doi.org/10.4322/rca.1975

\section{Copyrights}

Copyright for this article is retained by the author (s), with first publication rights granted to the journal.

This is an open-access article distributed under the terms and conditions of the Creative Commons Attribution license (http://creativecommons.org/licenses/by/4.0/). 